\title{
BDNF Modulates Contextual Fear Learning during Adolescence
}

\author{
Iva Dincheva ${ }^{a}$ b Siobhan S. Pattwell ${ }^{c}$ Lino Tessarollo ${ }^{d}$ Kevin G. Bath ${ }^{e}$ \\ Francis S. Lee ${ }^{a, b}$ \\ Departments of a Psychiatry and ${ }^{b}$ Pharmacology, Weill Cornell Medical College of Cornell University, \\ New York, N.Y., 'Department of Human Biology, Fred Hutchinson Cancer Research Center, Seattle, Wash., \\ dNeural Development Group, Mouse Cancer Genetics Program, Center for Cancer Research, National Cancer

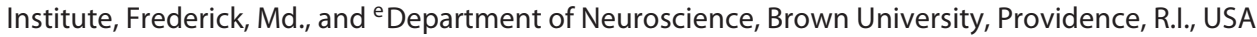

\section{Key Words}

Polymorphism · Development · Long-term memory · Brain-derived neurotrophic factor · TrkB.T1 .

Fear conditioning

\begin{abstract}
Brain-derived neurotrophic factor (BDNF) is a growth factor that plays key roles in regulating higher-order emotional and cognitive processes including fear learning and memory. A common single-nucleotide polymorphism (SNP) has been identified in the human BDNF gene (BDNF Val66Met) that leads to decreased BDNF secretion and impairments in specific forms of fear learning in adult humans and genetically modified mice containing this SNP. As the emergence of anxiety and other fear-related disorders peaks during adolescence, we sought to better understand the impact of this BDNF SNP on fear learning during the transition through adolescence in BDNF Val66Met knock-in mice. Previously, we have shown that contextual fear expression is temporarily suppressed in wild-type mice during a distinct period in adolescence, but re-emerges at later, postadolescent ages. Until recently, it was unclear whether BDNF-TrkB signaling is involved in the modulation of hippocampal-dependent contextual
\end{abstract}

I.D. and S.S.P. contributed equally to this work.

\section{KARGER}

(c) 2014 S. Karger AG, Base

0378-5866/14/0364-0269\$39.50/0

E-Mail karger@karger.com

www.karger.com/dne fear learning and memory during this adolescent period. Here we show that in BDNF Val66Met mice, the presence of the Met allele does not alter contextual fear expression during adolescence, but when previously conditioned BDNF ${ }^{\mathrm{Met} / \mathrm{Met}}$ mice are tested in adulthood, they fail to display the delayed expression of contextual fear compared to wild-type BDNF ${ }^{\mathrm{Val} / \mathrm{Val}}$ controls, indicating that the Met allele may permanently alter hippocampal function, leading to persistent functioning that is indistinguishable from the adolescent state. Conversely, truncated TrkB receptor (TrkB.T1)-deficient (TrkB.T1 ${ }^{-/-}$) mice, a genetic mouse model with increased BDNF-TrkB signaling through full-length TrkB receptors, exhibit an accelerated expression of contextual fear during adolescence compared to wild-type controls. Our results point to a critical function for BDNF-TrkB signaling in fear regulation in vivo, particularly during a potentially sensitive period in adolescence.

(c) 2014 S. Karger AG, Basel

\section{Introduction}

Brain-derived neurotrophic factor (BDNF) is a member of the neurotrophin growth factor family, which has been established to play key roles in the development

Kevin G. Bath

Department of Neuroscience, Brown University

Box GL-N, 185 Meeting Street

Providence, RI 02912 (USA)

E-Mail kevin_bath@brown.edu

Francis S. Lee

Department of Psychiatry

Weill Cornell Medical College of Cornell University

New York, NY 10065 (USA)

E-Mail fslee@ med.cornell.edu 
and plasticity of the central nervous system and has been implicated in neuropsychiatric disorders as well as learning and memory [1-3]. BDNF is expressed throughout the developing and mature brain, with highest levels expressed in the hippocampus [4]. A common single-nucleotide polymorphism (SNP) has been identified in the human $B D N F$ gene, which results in a nucleotide change from $\mathrm{G}$ to $\mathrm{A}$ at position 196 in the gene, as well as subsequent change in amino acid from valine to methionine at position 66 (e.g. Val66Met) in the prodomain of the BDNF protein. In vitro studies of hippocampal neurons have shown that this genetic alteration leads to impaired trafficking of BDNF, resulting in decreased levels of secreted mature BDNF and decreased activation of its receptor, TrkB $[5,6]$. The BDNF Val66Met polymorphism has been the focus of a large number of genetic association studies of cognitive function and a host of neuropsychiatric disorders. From these studies, it has also been associated with altered susceptibility to a variety of neuropsychiatric disorders including anxiety and depression [7-10], as well as alterations in cognitive processes involving the hippocampus $[5,11]$. In parallel, a variant BDNF Val66Met knock-in mouse has been generated, which reproduces the phenotypic hallmarks of humans with this polymorphism, especially with regard to alterations in hippocampal anatomy and behavior [5, $12,13]$.

While both human and mouse studies of this variant BDNF SNP have established alterations in the adult central nervous system, the impact of this genetic alteration on the developing brain is unclear, especially in light of the established findings that the expression of BDNF and its receptor, $\operatorname{TrkB}$, is dynamically regulated across postnatal development $[4,14-17]$. Of particular interest is the impact of this SNP on hippocampal function, as the development of this structure has been shown to continue throughout adolescence in both rodents and nonhuman primates $[18,19]$. Longitudinal studies of children and adolescents reveal that postnatal hippocampal maturation is not homogenous and that distinct maturational profiles exist for specific subregions [20]. The cause of these heterogeneous volume changes remains unknown, but it is hypothesized that they may be due to differences in neuronal proliferation, synaptic production and/or pruning. This heterogeneous postnatal development of hippocampal subregions correlates with contextual fear data from wild-type mice, showing that contextual fear expression during preadolescent ages is intact, temporarily suppressed during adolescence, and then re-emerges again during adulthood [21], supporting the notion that development is not a linear process in which neural maturation occurs uniformly in one direction or another. This temporary suppression of contextual fear is associated with alterations in synaptic activity as well as decreased hippocampal signaling of pathways downstream of TrkB receptors [21]. In order to determine whether BDNF-dependent signaling is involved in modulating contextual fear expression during this periadolescent time frame, we have utilized the $\mathrm{BDNF}_{\mathrm{Met}}$ knock-in mice in order to investigate the role of this Val66Met SNP in hippocampal-dependent fear learning and memory during adolescence. In order to extend our analyses, we have also performed parallel studies in a BDNF gain-of-function genetic mouse model, in which an endogenous dominant-negative form of the BDNF receptor, truncated TrkB (TrkB.T1), has been removed $[15,22]$, resulting in elevated BDNF-dependent signaling across postnatal development through full-length $\operatorname{TrkB}$ receptors.

\section{Methods}

\section{Animals}

The generation of $\mathrm{BDNF}^{\mathrm{Met} / \mathrm{Met}}$ mice was described previously [12]. Male BDNF ${ }^{\mathrm{Met} / \mathrm{Met}}$ mice and wild-type littermates derived from heterozygous $\mathrm{BDNF}^{+/ \mathrm{Met}}$ parents were used for all experiments. The generation of the TrkB.T1 $1^{-1-}$ mice has been described previously [22]. Male TrkB.T1 ${ }^{-/-}$mice and wild-type littermates derived from heterozygous $\mathrm{TrkB}^{\mathrm{T}} 1^{+/-}$parents were used for all experiments. All experiments were performed in accordance with institutional guidelines. The mice were genotyped as described previously $[12,15]$. Litters were weaned at postnatal day (PD) 21 and males from various litters were randomly combined to eliminate any litter-driven effects on behavior. The mice were housed 4-5 per cage in a temperature- and humidity-controlled vivarium maintained on a 12-hour light/dark cycle with ad libitum access to food and water. The same cohorts of mice, which were fear conditioned at PD29, were used for contextual fear testing in adolescence (after $24 \mathrm{~h}$ ) as well as in adulthood (after 2 weeks). Animal care was in compliance with guidelines established by Weill Cornell Medical College's Institutional Animal Care and Use Committee and the National Institutes of Health.

\section{Fear Conditioning}

The mice were fear conditioned in a mouse test cage (Coulbourn Instruments, Allentown, Pa., USA) inside a sound-attenuated box. The chamber (context A) was cleaned between each mouse and scented with peppermint-scented $(0.1 \%)$ ethanol (70\%). On conditioning day, following a 2-min acclimation period, the mice were conditioned with 3 presentations (trails) of a 30 -second tone $(5 \mathrm{kHz}, 70 \mathrm{~dB})$ that coterminated with a 1-second, $0.7-\mathrm{mA}$ foot shock delivered through the electrified floor grid. Each trial was separated by a 30 -second intertrial interval. After the final tone-shock pairing, the mice remained in the conditioning chamber for $1 \mathrm{~min}$ before being returned to their home cages. Memory for the context was assessed after $24 \mathrm{~h}$ (long-term mem- 
ory, LTM, test 1) and 2 weeks (LTM test 2) by returning the mice to context A. Freezing behavior was videotaped and scored during the last $3.5 \mathrm{~min}$ of the total $5.5 \mathrm{~min}$ spent in the chamber. After the contextual fear test, the mice were returned to their home cages. Memory for cue was assessed by placing the mice in a novel context, context B - a cylinder cleaned with lemon-scented $(0.1 \%)$ ethanol (70\%). After a 2 -min acclimation period in context $\mathrm{B}$, the mice were presented with $3 \times 30$-second tones $(5 \mathrm{kHz}, 70 \mathrm{~dB})$ separated by an intertrial interval of $30 \mathrm{sec}$. Freezing behavior was scored during each of the 30 -second tone presentations. After the last tone presentation, the mice remained in the novel context for $1 \mathrm{~min}$ before being returned to their home cages.

\section{Real-Time qPCR}

Total RNA was extracted from hippocampi of PD14, 21, 35 and 60, and 12-week-old male mice using Tri Reagent (Ambion, Austin, Tex., USA) following the 160 manufacturer's instructions. The reverse transcription reaction $(40 \mu \mathrm{l})$ contained $1 \times$ reaction buffer, $0.5 \mathrm{~mm}$ dNTPs, $1 \mu \mathrm{M} \mathrm{N} 7$ random primers, and the reverse transcriptase $(1 \mu \mathrm{l})$. cDNA was synthesized using $1.5 \mu \mathrm{g}$ of total RNA with MMuLV reverse transcriptase (New England Biolabs, Ipswich, Mass., USA). Reactions were incubated for $5 \mathrm{~min}$ at $25^{\circ} \mathrm{C}, 10$ min at $37^{\circ} \mathrm{C}$, and $1 \mathrm{~h}$ at $42^{\circ} \mathrm{C}$. cDNA was collected from the reverse transcription reaction using ethanol precipitation, followed by resuspension of the cDNA in Tris-EDTA buffer. The real-time PCR reactions for gene profiling were carried out in an ABI 7900HT real-time PCR machine (Applied Biosystems, Foster City, Calif., USA). For TrkB.FL and GAPDH, predesigned and validated primer sequences were chosen from the ABI TaqMan gene expression assay library (Applied Biosystems). For TrkB.T1, previously published primer sets were used to assess gene expression by SYBR green expression assay with melt curve to insure specificity. Amplified sequences were 60-120 bp long and exon spanning. PCR reactions were performed in triplicate with a minimum of 3 samples per group. Each reaction ( $5 \mu$ l total volume) contained either $2.5 \mu \mathrm{l}$ TaqMan gene expression assay buffer, with $1 \mu \mathrm{l}$ of cDNA as template and $0.3 \mu \mathrm{m}$ of each primer or $2.5 \mu \mathrm{l}$ SYBR gene expression assay buffer, with $1 \mu \mathrm{l}$ of cDNA as template and $0.3 \mu \mathrm{m}$ of each primer. Standard curves as well as no template controls were run in tandem with the samples. The reactions were incubated at $95^{\circ} \mathrm{C}$ for $10 \mathrm{~min}$ to activate the HotStar Taq polymerase followed by 40 cycles at $95^{\circ} \mathrm{C}$ for $15 \mathrm{~s}$ (denaturation) and at $60^{\circ} \mathrm{C}$ for $1 \mathrm{~min}$ (annealing and extension). The quantity of gene products was estimated based upon the generated standard curve (TaqMan) or melt curve (SYBR green) and corrected based upon the abundance of a control gene (GAPDH or $\beta$-actin).

\section{Results}

Recently, studies in wild-type mice have demonstrated a unique form of plasticity in fear learning in which contextual fear is developmentally suppressed during a defined period in periadolescence (PD29-39) but is retrieved at later, postadolescent ages (>PD40) [21]. To determine whether BDNF, which is developmentally regulated postnatally [4], is involved in regulating contex-

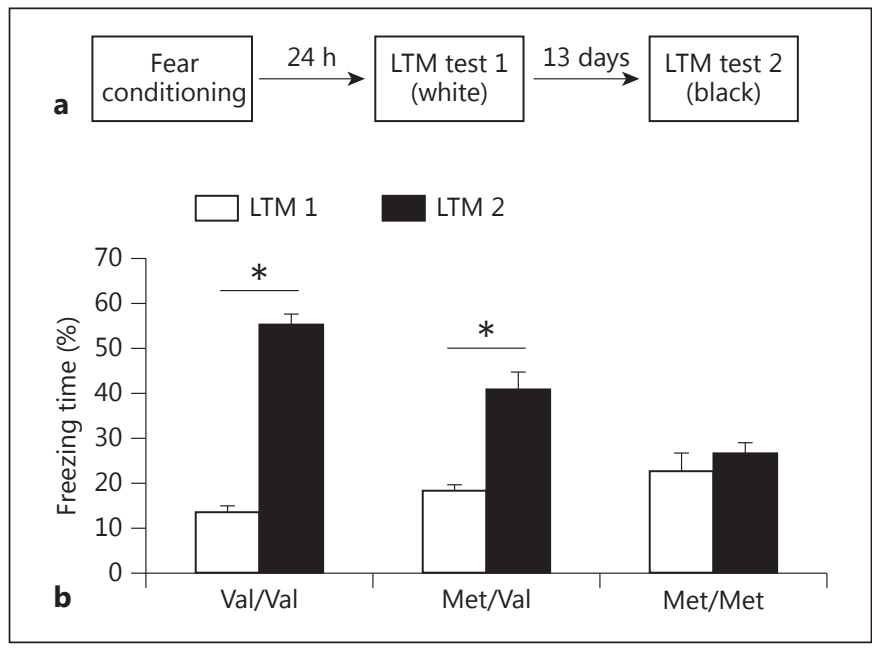

Fig. 1. Effect of BDNF Val66Met on adolescent suppression of contextual fear. a Schematic representation of behavioral paradigm. b The mice were fear conditioned with 3 tone-shock pairings; $24 \mathrm{~h}$ or 2 weeks after fear conditioning, the mice were placed back in the conditioning chamber and after a 2-min acclimation period contextual fear expression was measured as time spent freezing. All results are presented as mean \pm SEM determined from analysis of 7-14 mice per group. ${ }^{*} \mathrm{p}<0.001$.

tual fear expression during this periadolescent period, we fear conditioned $\mathrm{BDNF}^{\mathrm{Met} / \mathrm{Met}}$ mice at PD29 in context $\mathrm{A}$, and tested them the following day ( $24 \mathrm{~h}$ later) during LTM test 1 for contextual fear, also in context A (fig. 1a). We found that contextual fear was consistently low across all genotypes, recapitulating previous data obtained from wild-type, adolescent mice [21], suggesting that the hippocampal-dependent memory deficit in $\mathrm{BDNF}^{\mathrm{Met} / \mathrm{Met}}$ mice is not evident when all genotypes exhibit contextual fear suppression in adolescence (ANOVA, $\mathrm{F}_{2,30}=3.215$, $\mathrm{p}=0.054$; fig. 1b).

When these same mice were tested for contextual fear during LTM test 2, 2 weeks later during postadolescence/ early adulthood (PD43), the wild-type $\mathrm{BDNF}^{\mathrm{Val} / \mathrm{Val}}$ mice displayed the expected phenomenon of re-emergence of the previously learned contextual fear [21], whereas $\mathrm{BDNF}^{\mathrm{Val} / \mathrm{Met}}$ mice displayed only a moderate enhancement of contextual fear expression (ANOVA, $\mathrm{F}_{2,30}=$ 13.791, $\mathrm{p}<0.001$; fig. 1b). Interestingly, $\mathrm{BDNF}^{\text {Met/Met }}$ mice did not show any evidence of re-emergence of contextual fear expression after the 2-week delay (PD43; fig. 1b), suggesting that learning during the periadolescent period either continues to be suppressed or is altogether lost in these animals. This outcome is consistent with previous data in BDNF ${ }^{\text {Met/Met }}$ mice as well as human Met allele carriers showing decreased hippocampal mem- 
Fig. 2. Cue fear in BDNF Val66Met mice at PD29. The mice were fear conditioned with 3 tone-shock pairings; 24 h later, the mice were placed in a novel context to assess cue fear expression. Fear was measured as time spent freezing. All results are presented as mean \pm SEM determined from analysis of 2 mice per group.

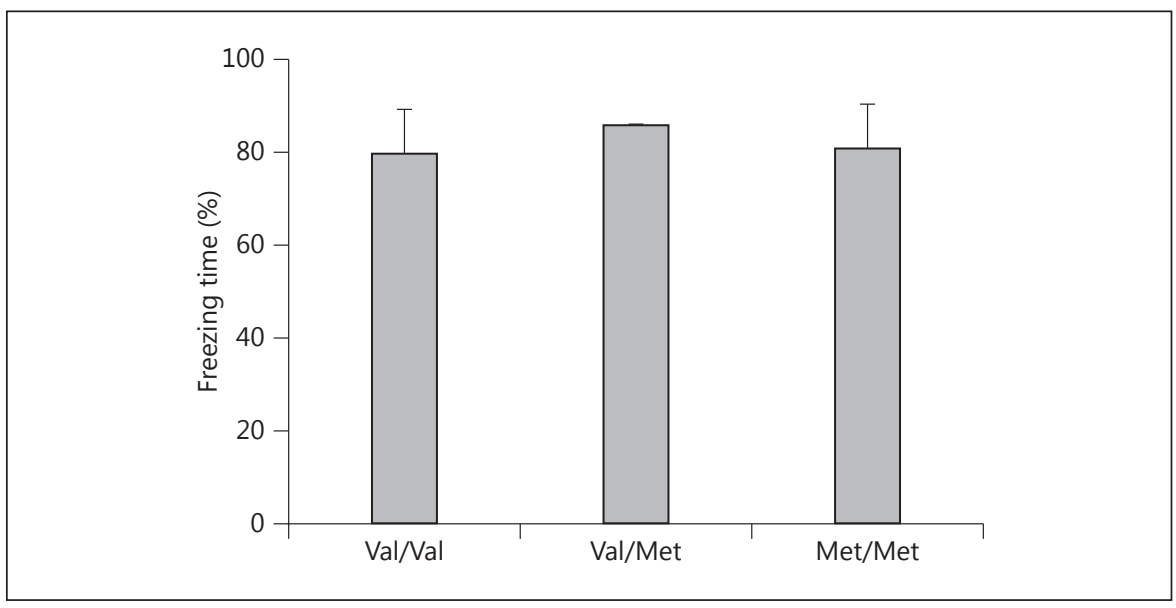

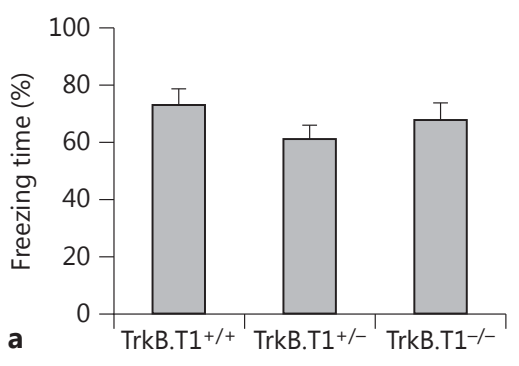

Fig. 3. Contextual and cue fear in TrkB.T1 $1^{-1-}$ mice. a Adult contextual fear. b Adult cue fear. c PD29 cue fear. The mice were fear conditioned with 3 tone-shock pairings; $24 \mathrm{~h}$ later, the mice were placed back in the conditioning chamber for contextual fear ex-

ory in adulthood $[5,12]$. In addition, amygdala-dependent cue memory is intact in both adulthood $[12,23,24]$ and adolescence in $\mathrm{BDNF}_{\text {Met }}$ mice (fig. 2), emphasizing the heightened vulnerability of the hippocampus to altered BNDF signaling.

While these developmental contextual fear results obtained with $\mathrm{BDNF}_{\mathrm{Met}}$ mice suggest that the decreased BDNF availability does not alter contextual fear behaviors during periadolescence per se, and that the $\mathrm{BDNF}_{\mathrm{Met}}$-associated impairments in contextual fear are observed later in life, we were interested in understanding the potentially contrasting effects that increased BDNF signaling may have on similar behavioral measures. To better address this question, we used a mouse line with a genetic deletion of one of BDNF's receptors, the truncated $\mathrm{TrkB}$ receptor (TrkB.T1 $1^{-/}$), which lacks the intracellular tyrosine kinase domain $[14,25]$. TrkB. $\mathrm{T} 1$ receptors have been primarily proposed to play a role as BDNF scavengers or dominant negative receptors se- pression (a) or in a novel context for cue fear expression (b, c). Fear was measured as time spent freezing. All results are presented as mean \pm SEM determined from analysis of 8-12 mice per group.

questering BDNF that would otherwise lead to activation of full-length TrkB receptors and downstream signaling cascades [15-17]. Cultured hippocampal neurons from TrkB.T1 ${ }^{-/-}$mice have shown enhanced BDNF-dependent TrkB receptor activation as well as enhanced downstream signaling in both the PI3K and MAPK pathways [22]. Thus, the TrkB.T1 $1^{-/-}$mouse line provides an opportunity to assess the impact of enhanced BDNF signaling during adolescence. In order to better allow for comparisons between TrkB.T1 and $\mathrm{BDNF}_{\mathrm{Met}}$ mice, initially adult $\mathrm{TrkB} . \mathrm{T1}^{-/-}$mice were tested on both contextual and cue fear learning. No genotypic differences were observed on either contextual or cue fear learning in adults, with TrkB.T1 $1^{+/}$, TrkB.T1 $1^{+/}$and TrkB.T1 ${ }^{-/-}$all showing equivalent levels of freezing (fig. $3 \mathrm{a}, \mathrm{b}$ ). This is consistent with previous data in this same mouse line, showing that TrkB.T1 does not affect hippocampal basal synaptic transmission and long-term potentiation or density of hippocampal neurons [15]. To explore the possibility 


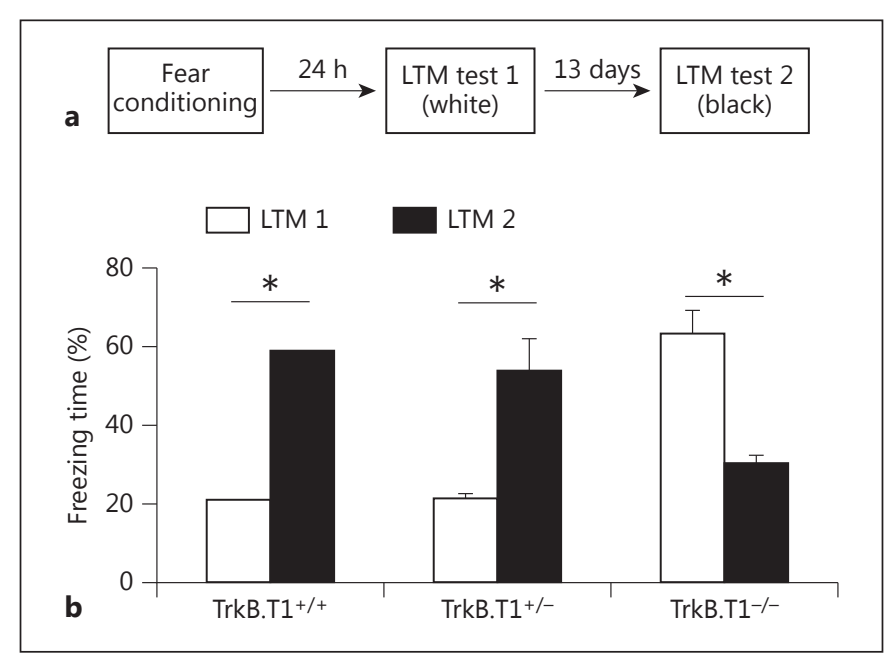

Fig. 4. Effect of TrkB.T1 loss on adolescent suppression of contextual fear. a Schematic representation of behavioral paradigm. b The mice were fear conditioned with 3 tone-shock pairings; $24 \mathrm{~h}$ or 2 weeks after fear conditioning, the mice were placed back in the conditioning chamber and after a 2-min acclimation period contextual fear expression was measured as time spent freezing. All results are presented as mean \pm SEM determined from analysis of $6-15$ mice per group. ${ }^{*} \mathrm{p}<0.001$.

that loss of TrkB.T1 may have differential effects during the sensitive period in adolescence, we fear conditioned separate cohorts of PD29 mice. We observed no effect of TrkB.T1 loss on cue fear learning (fig. 3c). In another cohort of mice, we tested PD29 TrkB.T1 $1^{+/+}$, TrkB.T1 $1^{+/-}$ and TrkB.T1 ${ }^{-/-}$mice on the same contextual fear paradigm as the Val66Met mice described above (fig. 4a). Based on previous results [21], we anticipated that periadolescent mice would display a lack of contextual fear, with a delay in significant increase in fear expression, occurring in adulthood. As expected, both TrkB.T1 $1^{+/+}$and TrkB.T1 ${ }^{+/-}$mice demonstrated delayed contextual fear expression, suggesting that partial loss of TrkB.T1 receptor does not result in developmental differences in contextual fear learning (fig. 4b). However, TrkB.T1 ${ }^{-/-}$mice displayed an opposite behavioral pattern, exhibiting significantly heightened contextual fear expression in adolescence compared to TrkB.T1 ${ }^{+/+}$and $\mathrm{TrkB} . \mathrm{T} 1^{+/-}$littermates (ANOVA, $\mathrm{F}_{2,18}=18.118$, $\mathrm{p}<0.001$; fig. $4 \mathrm{~b}$ ). Contextual fear in PD29 TrkB.T1 ${ }^{-/-}$mice is indistinguishable from adult contextual fear levels for control and heterozygous mice (fig. $4 \mathrm{~b}$ ), suggesting that complete loss of TrkB.T1 may have led to an enhanced functional maturation of hippocampal-amygdala-prefrontal circuitry. Furthermore, TrkB.T1 ${ }^{-l-}$ mice exhibit a significant decline in fear expression when tested in adulthood com-
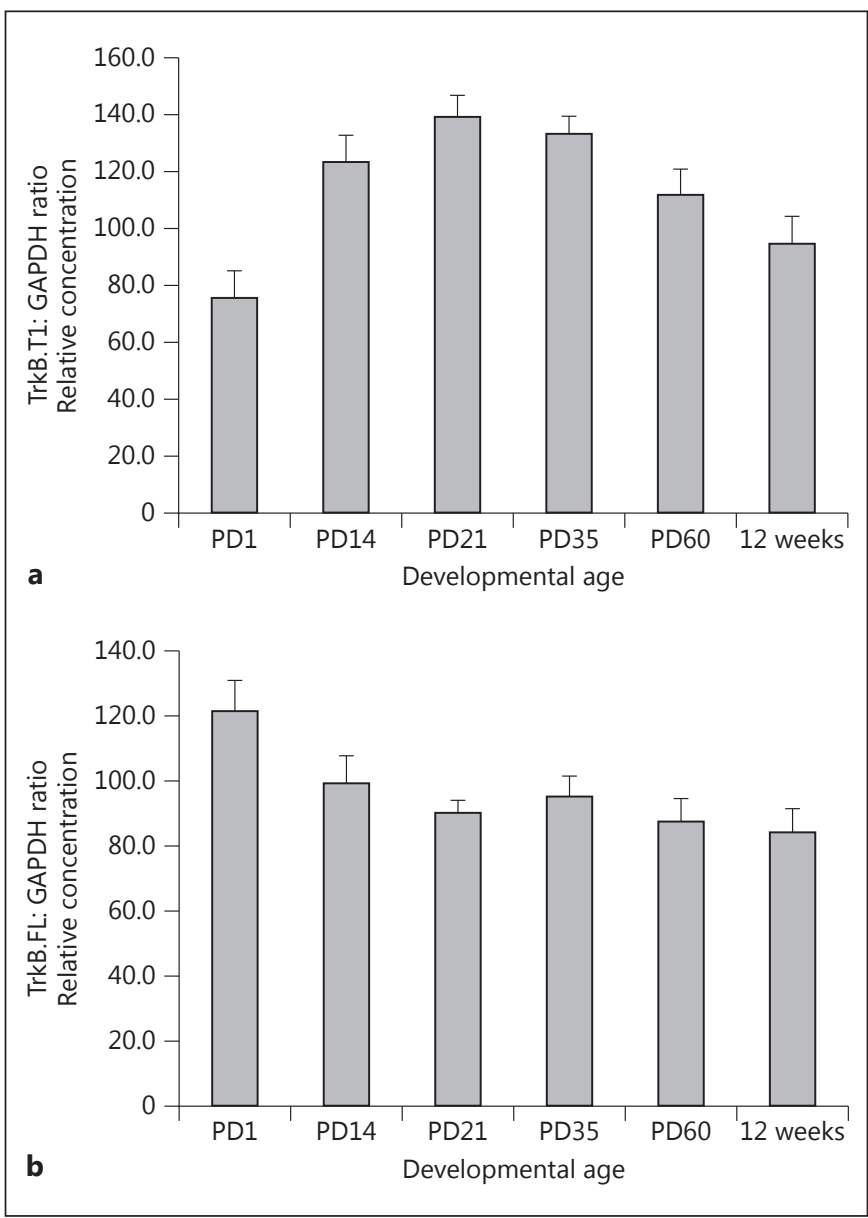

Fig. 5. mRNA expression of TrkB.T1 (a) and TrkB.FL (b) in the developing hippocampus. Total RNA was extracted from hippocampi at various ages. Gene expression was assessed by using SYBR green or TaqMan gene expression assay buffer. All results are presented as mean \pm SEM determined from analysis of 3 mice per postnatal age group per genotype.

pared to other genotypes (fig. 4b). We take these data to suggest that the association of the context with the aversive stimulus may have been extinguished during re-exposure of the context during adolescence. Because endogenous TrkB.T1 levels peak in this periadolescent time frame whereas full-length TrkB receptor expression remains constant across postnatal development (fig. 5), a loss of this dominant negative form of TrkB, particularly during adolescence, may result in increased signaling through full-length TrkB, which has been shown to have important roles in long-term potentiation, learning and memory [3]. As such, mice lacking the truncated form of the BDNF receptor TrkB.T1 may have undergone more rapid neural maturation, resulting in enhanced capacity for learning during this age. 


\section{Discussion}

The main finding of our study is that expression of contextual fear, acquired in adolescence but suppressed until adulthood, is modulated by altering BDNF-TrkB signaling. Using genetic models of altered BDNF-TrkB signaling, we show that contextual fear undergoes further suppression in adulthood in $\mathrm{BDNF}^{\mathrm{Met} / \mathrm{Met}}$ mice, with decreased BDNF availability. However, in TrkB. $\mathrm{T}^{-/-}$mice that have increased BDNF-dependent TrkB signaling, fear expression is heightened in adolescence but is subsequently attenuated in adulthood compared to other genotypes. Because BDNF signaling through TrkB receptors has been shown to play an essential role in hippocampus-mediated learning [26, 27], these studies suggest the possibility of BDNF's involvement in setting up the sensitive period for adolescent suppression of contextual fear expression observed in wild-type mice.

The hippocampus, along with prefrontal and limbic structures, is a primary regulator of contextual fear expression. Specifically, projections from the hippocampal CA1 region to the basal nucleus of the amygdala process contextual fear acquisition $[28,29]$. Lesions to the dorsal hippocampus disrupt both acquisition and expression of contextual fear [29-31]. Interestingly, the hippocampus is one of several structures in the brain involved in cognitive processing, which reaches maturity in late development. Hippocampal growth continues throughout adolescence in both rodents and nonhuman primates [18, 19]. Furthermore, longitudinal scans of children and adolescents (between the ages of 4 and 25 years) reveal that postnatal hippocampal maturation is not uniform throughout the structure and that distinct maturational profiles exist for specific subregions [20]. This late maturation of the hippocampus is well demonstrated by the finding that contextual fear expression is intact in preadolescence, then temporarily suppressed during adolescence, and subsequently re-emerges in adulthood [21]. Our results suggesting that alterations in BDNF-TrkB signaling have a profound effect on contextual fear expression during adolescence are in accordance with data showing that the hippocampus is still undergoing plastic changes and can be modified at this developmental period $[18,19,32]$.

One finding of the current work is that TrkB.T1 $1^{-/-}$ mice do not demonstrate suppression of contextual fear during the sensitive period in adolescence, which is observed in wild-type mice (fig. 4b). It is intriguing to speculate whether increased BDNF signaling through full- length TrkB receptors in these knock-out mice leads to early hippocampal maturation, particularly of the neural circuitry involved in contextual fear regulation. Thus, the sensitive period is shifted to an earlier developmental stage. In addition, as endogenous TrkB.T1 receptor levels normally peak during this periadolescent period (fig. 5), it is possible that during the transition into adolescence there is attenuation of baseline BDNF-dependent TrkB signaling that is due to this surge in TrkB.T1 receptors and which may contribute in setting up this periadolescent development window of contextual fear suppression. Furthermore, TrkB.T1 ${ }^{-/-}$mice, unlike control littermates, do not subsequently exhibit the high levels of contextual fear expression in adulthood that is observed in wild-type mice [21]. One explanation for this observation may be that the early maturation of the hippocampus leads to enhanced fear learning during adolescence; thus re-exposure of the context $24 \mathrm{~h}$ after conditioning is effectively an extinction session dissociating the context from the unconditioned stimulus. Therefore, the context is no longer perceived as a significant threat in adulthood. In the future, it will be of interest to further test this hypothesis and also create conditional deletion of the TrkB. $\mathrm{T} 1$ receptor in specific brain regions and developmentally restricted time points in order to parse out the circuitry involved.

Another finding of our study is that $\mathrm{BDNF}^{\mathrm{Met} / \mathrm{Met}}$ mice exhibit blunted contextual fear expression in adulthood comparable to those in adolescence (fig. 1b). The results suggest that the decreased BDNF availability in these mice delays maturation of the hippocampal learning and memory circuitry. BDNF ${ }^{\mathrm{Met} / \mathrm{Met}}$ mice have previously been shown to exhibit contextual fear deficits in adulthood along with decreased hippocampal size, dendritic complexity and plasticity deficiencies [12, 33]. Thus, it is unclear whether learning and memory circuitry ever reaches maturation or if it is locked into an immature state presumably due to lack of trophic support. In addition, wild-type mice have been shown to exhibit high levels of contextual fear expression prior to entering the sensitive period in adolescence at PD29. It would be beneficial to investigate whether $\mathrm{BNDF}^{\mathrm{Met} / \mathrm{Met}}$ mice exhibit comparable levels of contextual fear at that early age and BDNF-dependent hippocampal deficits emerge during the transition from adolescence to adulthood. A better understanding of learning and memory deficits associated with the $\mathrm{BDNF}_{\mathrm{Met}}$ allele may prove helpful for the development of better clinical strategies for the prevention and treatment of neuropsychiatric disorders. 
Finally, with regard to the implications for the human BDNF Val66Met SNP, the absence of delayed contextual fear expression observed in $\mathrm{BDNF}^{\mathrm{Met} / \mathrm{Met}}$ mice may be suggestive of an adaptive role in protecting BDNF Met allele carriers from re-experiencing previously conditioned aversive fears, despite their increased tendency for higher anxiety-like behavior in adulthood [12,34]. Future studies are needed to investigate this apparent discrepancy between high anxiety-like behavior during adulthood and a lack of expression of previously conditioned

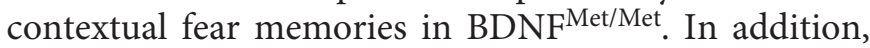

understanding this phenomenon may shed light on the effects of the BDNF $\mathrm{Met}_{\text {et }}$ allele on the long-term behavioral consequences of early-life stress.

\section{Acknowledgments}

This work was supported by the Sackler Institute (B.J.C.), the DeWitt-Wallace Fund of the New York Community Trust (F.S.L.), the Pritzker Consortium (F.S.L.), the Youth Anxiety Center (F.S.L.) and National Institutes of Health grants HD055177 (to B.J.C. and S.S.P.), MH079513 (to B.J.C. and F.S.L.) and NS052819 (to F.S.L.).

\section{References}

1 Poo MM: Neurotrophins as synaptic modulators. Nat Rev Neurosci 2001;2:24-32.

-2 Huang EJ, Reichardt LF: Neurotrophins: roles in neuronal development and function. Annu Rev Neurosci 2001;24:677-736.

-3 Chao MV: Neurotrophins and their receptors: a convergence point for many signalling pathways. Nat Rev Neurosci 2003;4: 299-309.

4 Katoh-Semba R, Takeuchi IK, Semba R, Kato $\mathrm{K}$ : Distribution of brain-derived neurotrophic factor in rats and its changes with development in the brain. J Neurochem 1997;69:3442.

5 Egan MF, Kojima M, Callicott JH, Goldberg TE, Kolachana BS, Bertolino A, Zaitsev E, Gold B, Goldman D, Dean M, Lu B, Weinberger DR: The BDNF Val66Met polymorphism affects activity-dependent secretion of BDNF and human memory and hippocampal function. Cell 2003;112:257-269.

6 Chen ZY, Patel PD, Sant G, Meng CX, Teng KK, Hempstead BL, Lee FS: Variant brain-derived neurotrophic factor (BDNF) (Met66) alters the intracellular trafficking and activitydependent secretion of wild-type BDNF in neurosecretory cells and cortical neurons. J Neurosci 2004;24:4401-4411.

-7 Momose Y, Murata M, Kobayashi K, Tachikawa M, Nakabayashi Y, Kanazawa I, Toda T: Association studies of multiple candidate genes for Parkinson's disease using single nucleotide polymorphisms. Ann Neurol 2002; 51:133-136.

-8 Sklar P, Gabriel SB, McInnis MG, Bennett P, Lim Y, Tsan G, Schaffner S, Kirov G, Jones I, Owen M, Craddock N, DePaulo JR, Lander ES: Family-based association study of 76 candidate genes in bipolar disorder: BDNF is a potential risk locus. Mol Psychiatry 2002;7: 579-593.

-9 Ventriglia M, Bocchio Chiavetto L, Benussi L, Binetti G, Zanetti O, Riva MA, Gennarelli M: Association between the BDNF 196 A/G polymorphism and sporadic Alzheimer's disease. Mol Psychiatry 2002;7:136-137.
10 Sen S, Nesse RM, Stoltenberg SF, Li S, Gleiberman L, Chakravarti A, Weder AB, Burmeister M: A BDNF coding variant is associated with the neo personality inventory domain neuroticism, a risk factor for depression. Neuropsychopharmacology $\quad 2003 ; 28: 397-$ 401.

11 Hariri AR, Goldberg TE, Mattay VS, Kolachana BS, Callicott JH, Egan MF, Weinberger DR: Brain-derived neurotrophic factor Val$66 \mathrm{Met}$ polymorphism affects human memory-related hippocampal activity and predicts memory performance. J Neurosci 2003;23: 6690-6694.

12 Chen ZY, Jing D, Bath KG, Ieraci A, Khan T, Siao CJ, Herrera DG, Toth M, Yang C, McEwen BS, Hempstead BL, Lee FS: Genetic variant BDNF (Val66Met) polymorphism alters anxiety-related behavior. Science 2006; 314:140-143.

13 Bueller JA, Aftab M, Sen S, Gomez-Hassan D, Burmeister M, Zubieta JK: BDNF Val66Met allele is associated with reduced hippocampal volume in healthy subjects. Biol Psychiatry 2006;59:812-815.

14 Fryer RH, Kaplan DR, Feinstein SC, Radeke MJ, Grayson DR, Kromer LF: Developmental and mature expression of full-length and truncated TrkB receptors in the rat forebrain. J Comp Neurol 1996;374:21-40.

15 Carim-Todd L, Bath KG, Fulgenzi G, Yanpallewar S, Jing D, Barrick CA, Becker J, Buckley H, Dorsey SG, Lee FS, Tessarollo L: Endogenous truncated TrkB.T1 receptor regulates neuronal complexity and TrkB kinase receptor function in vivo. J Neurosci 2009;29: 678-685.

-16 Biffo S, Offenhauser N, Carter BD, Barde YA: Selective binding and internalisation by truncated receptors restrict the availability of BDNF during development. Development 1995; 121:2461-2470.

17 Eide FF, Vining ER, Eide BL, Zang K, Wang XY, Reichardt LF: Naturally occurring truncated TrkB receptors have dominant inhibitory effects on brain-derived neurotrophic factor signaling. J Neurosci 1996;16:31233129.

18 Benes FM, Turtle M, Khan Y, Farol P: Myelination of a key relay zone in the hippocampal formation occurs in the human brain during childhood, adolescence, and adulthood. Arch Gen Psychiatry 1994;51:477-484.

19 Kornack DR, Rakic P: Continuation of neurogenesis in the hippocampus of the adult macaque monkey. Proc Natl Acad Sci USA 1999; 96:5768-5773.

20 Gogtay N, Nugent TF 3rd, Herman DH, Ordonez A, Greenstein D, Hayashi KM, Clasen L, Toga AW, Giedd JN, Rapoport JL, Thompson PM: Dynamic mapping of normal human hippocampal development. Hippocampus 2006; 16:664-672.

21 Pattwell SS, Bath KG, Casey BJ, Ninan I, Lee FS: Selective early-acquired fear memories undergo temporary suppression during adolescence. Proc Natl Acad Sci USA 2011;108: 1182-1187.

22 Dorsey SG, Renn CL, Carim-Todd L, Barrick CA, Bambrick L, Krueger BK, Ward CW, Tessarollo L: In vivo restoration of physiological levels of truncated TrkB.T1 receptor rescues neuronal cell death in a trisomic mouse model. Neuron 2006;51:21-28.

23 Pattwell SS, Bath KG, Perez-Castro R, Lee FS, Chao MV, Ninan I: The BDNF Val66Met polymorphism impairs synaptic transmission and plasticity in the infralimbic medial prefrontal cortex. J Neurosci 2012;32:2410-2421.

24 Soliman F, Glatt CE, Bath KG, Levita L, Jones RM, Pattwell SS, Jing D, Tottenham N, Amso D, Somerville LH, Voss HU, Glover G, Ballon DJ, Liston C, Teslovich T, Van Kempen T, Lee FS, Casey BJ: A genetic variant BDNF polymorphism alters extinction learning in both mouse and human. Science 2010;327:863866.

25 Middlemas DS, Lindberg RA, Hunter T: TrkB, a neural receptor protein - tyrosine kinase: evidence for a full-length and two truncated receptors. Mol Cell Biol 1991;11:143153. 
26 Minichiello L, Korte M, Wolfer D, Kuhn R, Unsicker K, Cestari V, Rossi-Arnaud C, Lipp HP, Bonhoeffer T, Klein R: Essential role for TrkB receptors in hippocampus-mediated learning. Neuron 1999;24:401-414.

27 Silhol M, Arancibia S, Maurice T, TapiaArancibia L: Spatial memory training modifies the expression of brain-derived neurotrophic factor tyrosine kinase receptors in young and aged rats. Neuroscience 2007; 146 : 962-973.

28 Bouton ME, Westbrook RF, Corcoran KA, Maren S: Contextual and temporal modulation of extinction: behavioral and biological mechanisms. Biol Psychiatry 2006;60:352-360.
29 Phelps EA, LeDoux JE: Contributions of the amygdala to emotion processing: from animal models to human behavior. Neuron 2005; 48:175-187.

30 Kim JJ, Fanselow MS: Modality-specific retrograde amnesia of fear. Science 1992;256: 675-677.

31 Selden NR, Everitt BJ, Jarrard LE, Robbins TW: Complementary roles for the amygdala and hippocampus in aversive conditioning to explicit and contextual cues. Neuroscience 1991;42:335-350.
32 Peters A: Golgi, Cajal, and the fine structure of the nervous system. Brain Res Rev 2007;55: 256-263.

33 Ninan I, Bath KG, Dagar K, Perez-Castro R, Plummer MR, Lee FS, Chao MV: The BDNF Val66Met polymorphism impairs NMDA receptor-dependent synaptic plasticity in the hippocampus. J Neurosci 2010;30:88668870.

34 Spencer JL, Waters EM, Milner TA, Lee FS, McEwen BS: BDNF variant Val66Met interacts with estrous cycle in the control of hippocampal function. Proc Natl Acad Sci USA 2010;107:4395-4400. 